\title{
MARKETING
}

RECEIVED:

10 September 2021

ACCEPTED:

01 October 2021

RELEASED:

20 October 2021
UDC 339.138(594):656.131-052]:004.738.5

DOI 10.26661/2522-1566/2021-3/17-06

\section{IN-DRIVER ONLINE TAXI AND DRIVERS BEHAVIOR AS A PART OF MARKETING MIX PROGRAM}

\author{
Lydia Goenadhi* \\ Sekolah Tinggi Ilmu Ekonomi Indonesia \\ Banjarmasin, Indonesia \\ ORCID : 0000-0002-3077-7844
}

\author{
Mohdari \\ STIE Nasional Banjarmasin \\ Banjarmasin, Indonesia \\ ORCID: 0000-0001-5563-405X
}

\section{Sri Wahyunawati \\ STIE Dahani Dahanai Buntok \\ Indonesia \\ ORCID: 0000-0002-4209-7678}

*Corresponding author email: goenadhilydia@gmail.com

\begin{abstract}
In Indonesia, nowadays, private vehicles, such as cars, also function as public transportation carrying people/goods and charging agreed fees. This mode of transportation is known as an online taxi. Along with the advancement of technology, current applications appear to introduce online transportation ordering services using technology and service standards. Based on these phenomena, some online taxi service providers are existing in Banjarmasin, such as Grab-Car, Go-Car, Maxim, and In-Driver. All services provided are almost the same in transporting people with similar booking systems through an application already installed on the cellphone online, but they have different prices. The number of recent developing online taxis causes the competition to be even tougher. This competition occurs because the price and service are the factors determining consumers' satisfaction and preference. Hence, online taxi companies attempt to create quality service and appropriate prices to meet consumers' satisfaction. This study aimed to determine the role of the marketing mix program and drivers' behavior while driving on the consumer satisfaction with online in-driver taxis in Banjarmasin. This research employed path analysis. The population of this study involved 121 consumers of in-drive taxis in Banjarmasin. The samples were taken from the population through the census method. The results of this study showed that product, price, and promotion had a positive and significant effect on the consumer satisfaction with in-drive taxis in Banjarmasin, and these three variables also positively and significantly affected the drivers' behavior of in-drive taxi drivers while driving in Banjarmasin. Simultaneously, product, price, place, and promotion had a positive and significant impact on the consumer satisfaction with indriver taxis in Banjarmasin through the drivers' behavior of the in-driver taxi in Banjarmasin while driving as an intervening variable.
\end{abstract} taxi.

Keywords: product, price, promotion, place,driver's behavior, consumer satisfaction,online

JEL Classification: M10, M31,O18. 
Goenadhi, L., Mohdari., Wahyunawati, S. (2021), "In-driver online taxi and drivers behavior as a part of marketing mix program”, Management and entrepreneurship: trends of development, 3(17), pp. 68-82. Available at: https://doi.org/10.26661/2522-1566/2021-3/17-06.

\section{INTRODUCTION}

The better the economic level of a community, in general, the society will obtain a higher income. The great income may highly affect the level of prosperity, the standard of living, the need for clothing, foods, and houses, and even changes the community lifestyle. The better the people's standards of living, the demands to meet their needs are getting higher as well. Nowadays, people have various activities. To fulfill these activities, people often need transportation as a supporting tool. Therefore, transportation service entrepreneurs are competing to capture the consumers' attention by improving service, ease of ordering, fleet comfort, punctuality, and so on. In Indonesia, some vehicles, such as cars, also function as public transportation that can transport people/goods and charge agreed fees. This mode of transportation is known as an online taxi. Along with the advancement of technology, current applications appear to introduce online transportation ordering services using technology and service standards. Previously, online taxis used a metered order system and online taxi drivers had to go through manual transactions. Even to use online taxi services, the service users had to pay cash and often bargain. Based on the survey results of the Indonesian Internet Service Providers Association, in the 2019-quarter II/2020 period, Grab and Gojek were the most frequently used online transportation application services by the public. There were $21.3 \%$ of respondents admitting that they often used the Grab application to travel. Meanwhile, $19.4 \%$ of respondents admitted that they often utilized the Gojek application when they wanted to travel. The respondents who chose other online transportation application services, such as Anterin, Bonceng, Maxim, and FastGo, ranged from $0.1 \%-0.3 \%$. Meanwhile, $58.1 \%$ of the respondents claimed to have never used online transportation application services (https://databoks.katadata.co.id/datapublish/2020/11/11/). Based on data from Spire Research and Consulting, consumers preferred to order car delivery services of Grab than GoJek. Until quarter 4/2018, 34\% of GrabCar users said that they used the Grab service 3-4 times per week. Meanwhile, $25 \%$ of Go-Car users tended to only order the service 1-2 times a week (https://gadgetsquad.id/versus/gojek-vs-grab/). Currently, some online taxi service providers are existing in Banjarmasin, such as Grab-Car, Go-Car, Maxim, In-Driver. All services provided are almost the same, namely delivering people at different prices but with the same ordering system, namely through an application already installed on the cellphone. The number of recent developing online taxis causes the competition to be even tougher. This competition occurs because the price and service are the factors determining consumers' satisfaction and preference. Hence, online taxi companies attempt to create quality service and appropriate prices to meet consumers' satisfaction.

PT. Grab Indonesia is an online transportation service company providing Grab Car, Grab Bike, Grab Express, Grab Taxi services. The Grab service presents an alternative transportation service for drivers and passengers emphasizing speed, safety, and certainty. Grab started to present in Indonesia in 2012 as a taxi booking application and since then it has provided various transportation options, such as cars and online taxis. In 2017 Grab began to exist in Banjarmasin City as one of the online transportation service providers growing in Banjarmasin. In Banjarmasin, Grab provides Grab Car, Grab Bike, Grab Food, Grab Delivery services. Grab is an online transportation application that simply requires ordering through an application on a mobile phone and the drivers will contact the customer to ensure the location has been determined in the application to make them easier to pick up the prospective passengers. Retaining and satisfying consumers are more practical than constantly looking for new customers since the cost of maintaining the customers is lower than the cost of finding new customers. Satisfied consumers can support the harmonious relationship between the company and consumers, provide a good basis for repeat purchases, create customers' loyalty, become an advisor for the company, especially when the reputation of the company or product is harassed by others, and invite positive recommendations profitable for the company. 
One of the factors affecting consumer satisfaction is running a marketing mix program and the behavior of online taxi drivers running service quality. Lupiyoadi and Hamdani (2014) suggested that the quality of service applied to drivers' behavior greatly influenced consumers' satisfaction, where good service had a greater effect on consumer satisfaction. Although services are intangible goods, they can be assessed based on one's experience and reasoning. Service quality can impact customer satisfaction because of the interaction between consumers and the company. Based on the concept of consumer satisfaction, the perceived performance or results should be following consumer expectations. Therefore, the service quality provided by the company mainly affects customer satisfaction. The marketing mix has four significant aspects that will influence consumer satisfaction. Hence, it is necessary to identify how much effect is given by each aspect of the marketing mix, including both direct and indirect effects on loyalty. In fact, the marketing mix consisting of product, price, distribution, and promotion has been implemented by the company where products with different flavors are relatively good, the prices are relatively cheap, distribution is well established, and promotions have been implemented. This is in line with the behavioral role of Grab Car online taxi drivers. The study aimed to determine the role of the marketing mix program and drivers' behavior on in-driver online taxi consumer satisfaction in Banjarmasin. Specifically, this research intended to investigate the direct and indirect effects of the role of the marketing mix program and drivers' behavior on in-driver online taxi consumer satisfaction in Banjarmasin.

Due to the rapid company development level and changes in consumer desires, companies need to develop existing products to meet consumer wants and needs. Every company should sell its products to survive and grow. Direct or indirect marketing activities support selling the products of the company. The marketing mix is a set of controlled marketing variables used by the company to achieve its target market. The marketing mix consists of some aspects of product, price, distribution, and promotion. These aspects are one of the factors that can affect the success of a company while interacting with the market environment to increase the volume of product sales. The marketing mix is also defined as organizational elements that are controllable and useable by companies to satisfy or to communicate with consumers (Zeithaml and Bitner, 1996:23). The marketing mix refers to an integrated strategy consisting of product, price, promotion, distribution (Place). Each element of the marketing mix requires input from consumer observations, so the company will understand the buyer's behavior. Understanding buyer behavior will provide clues to companies to develop new products, product features, prices, marketing channels, which can be accepted by buyers or consumers and may enable companies to issue more innovative products.

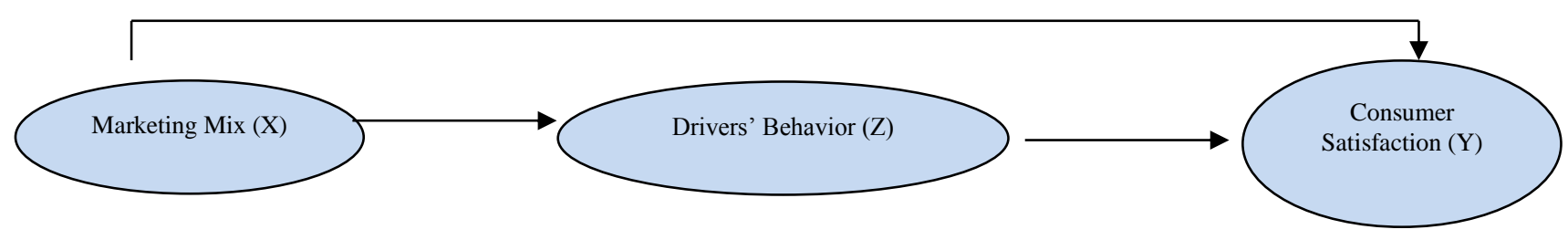

Figure 1 Framework Model

\section{LITERATURE REVIEW}

In the world of commerce, we often hear the term marketing confused with selling. Selling is only one part of marketing activities, namely one part of a promotion. Meanwhile, promotion is one part of the overall marketing programs.Marketing acts as a liaison between the needs of the community and the pattern of the industry's response. Meanwhile, marketing management is an aspect determining the company's success in surviving.

Marketing Mix 
Goenadhi, L., Mohdari., Wahyunawati, S. (2021), "In-driver online taxi and drivers behavior as a part of marketing mix program”, Management and entrepreneurship: trends of development, 3(17), pp. 68-82. Available at: https://doi.org/10.26661/2522-1566/2021-3/17-06.

The Marketing Mix is a key concept in modern marketing theory. Kotler. (2016: 82) defined marketing mix as a mixture of controllable marketing variables used by a company to pursue the desired level of sales in the target market. Marketing is inseparable from marketing variables. These marketing variables are often called the 4Ps consisting of Product, Price, Place, and Promotion. From the definition of the marketing mix, we can conclude that the four elements of the marketing mix are tools controllable by the companies in satisfying the target market. These four elements are interrelated with one another. This means that the decision of one element will affect the other elements. Therefore, the company must be able to combine the four aspects most suitable for the existing environment.

\section{Product}

Assauri (2013), a product is anything that a producer can offer to be noticed, requested, sought, purchased, used to fulfill the needs or desires of the relevant market. Products offered include physical goods, services, people, places, organizations, and ideas.

\section{Price}

Aini (2013), pricing includes determining the price for a product so that it usually generates profits. Pricing is very influential on the survival of the organization in the long term for the following two reasons. First, the price and the number of goods sold at that price determine the revenue earned or profits earned and improper pricing will cause the product to be eliminated from the market.

\section{Place (Places interconnected through distribution)}

Saladin (2002), the third element of this marketing mix is a variety of activities carried out by the company to distribute its products to consumers who need and want them at the right place and time. Broadly speaking, distribution can be interpreted as a marketing activity seeking to facilitate the delivery of goods and services from producers to consumers, so that their use is in accordance with the needs (type, quantity, price, place, and time needed).

\section{Promotion}

Jakaria and Esti (2012), promotion is one of the determining factors for the success of a marketing program. No matter how good a product is if consumers have never known of it and are uncertain that the product will be useful to them, and then they will never buy it. In essence, promotion is a form of marketing communication seeking to disseminate information, influence or persuade, and remind the target market of the company and its products to be willing to accept, buy, and be loyal to the products offered. Although in general, the forms of promotion have the same function, these forms can be distinguished based on their specific tasks. Some of these special duties are often called the promotional mix consisting of advertising, personal selling, sales promotion, and publicity.

\section{Consumer Satisfaction}

Kotler who was quoted by Fandy Tjiptono (2011: 312), consumer satisfaction is the level of a person's feelings after comparing the performance (or results) he perceives to his expectations. Kotler and Keller (2009), satisfaction is a person's feelings of pleasure or disappointment arising from comparing the perceived performance of the product (or outcome) against his expectations. If performance fails to meet expectations, consumers will be dissatisfied, and vice versa. If the performance exceeds expectations, the consumer will be very satisfied or happy. Based on those definitions, it can be concluded that consumer satisfaction is behaviors, justifications, and emotional responses expressed by consumers after purchasing/consuming products as the comparison of their expectations to the actual performance, as well as evaluation to their experiences in consuming a certain product or service. The Consumer Satisfaction Indicators, Tjiptono (2004:101) include conformity of expectations, interest in revisiting, and willingness to recommend.

\section{Drivers' Behaviors}

Behavior is a set of an individual's actions or activities in responding to something and then becoming a habit because of the values believed in. Human behavior is essentially the human's acts 
or activities both observable and unobservable by interacting with their environment manifested in the form of knowledge, attitudes, and actions. More rationally, behavior can be interpreted as the response of an organism or a person to stimuli from outside the subject. This response is in the form of two types, namely the passive and the active forms where the passive form is an internal response occurring in humans and it cannot be directly seen by others, while the active form is when the behavior is directly observable (Oentoro, 2010). Behaviors are all the biological manifestations of individuals in interacting with the environment, from the most visible to the invisible behaviors, from the perceived to the least perceived behaviors (Bilson, 2002). Behavior is the result of all kinds of human experiences and interactions with the environment manifested in the form of knowledge, attitudes, and actions. Behavior is an individual's response/reaction to stimuli coming from the outside or within himself (Notoatmojo, 2010). Meanwhile, Wawan and Dewi (2011), behavior is an observable action having a specific frequency, duration, and purpose. Behavior is a collection of various interacting factors.

\section{METHODOLOGY}

\section{Research Object}

The object in this research is the marketing mix, with the scope of the role of the marketing mix program and drivers' behavior on the satisfaction with in-driver online taxi consumers in Banjarmasin.

\section{Research Method}

In this study, the authors researched the role of the marketing mix program and drivers' behavior on the satisfaction with in-driver online taxi consumers in Banjarmasin. This research employed a descriptive-analytical research method (Moh. Nazir, 1988).

\section{Research Design}

This research was carried out to determine the direct and indirect effects of the marketing mix program and drivers' behavior on the satisfaction with in-driver online taxi consumers in Banjarmasin. This study also performed statistical testing of the influence given by the marketing mix on consumer loyalty, whether it was significant or not. This research was executed by emphasizing the data from the questionnaire processed using the Path Analysis method.

\section{Population and Samples}

The samples in this study were taken by using the following methods: The population of this research involved 121 consumers using In-Drive taxi Banjarmasin for a month in the Banjarmasin. To determine the sample size, a census method was employed, that Sugiyono (2017), in census method, the samples selected are part of the population.

\section{Data Analysis Method}

The effects of intervening variables were tested using the path analysis method. Analysis Path is an extension of multiple linear regression analysis where the use of regression analysis is to estimate the causality relationship between variables (casual model) set previously based on theory. Workload and individual behavior variables related to employee performance were mediated by employee perception. So, the regression analysis consists of:

1. Independent variables: product $(\mathrm{X} 1)$, price $(\mathrm{X} 2)$, place $(\mathrm{X} 3)$, and promotion $(\mathrm{X} 4)$

2. Dependent variable: consumer satisfaction (Y)

3. Intervening Variables: In-Drive Taxi Drivers' Behavior in Banjarmasin (Z)

The structural equation models in this study are:

1. Equation 1: $\mathrm{Y}=\mathrm{PY} 1 \mathrm{X} 1 \mathrm{X} 1+\rho \mathrm{Y} 1 \mathrm{X} 2 \mathrm{X} 2+\mathrm{e} 1$

2. Equation $2: \mathrm{Z}=\rho \mathrm{Y} 1 \mathrm{X} 1+\rho \mathrm{Y} 1 \mathrm{X} 2+\mathrm{e} 1$

3. Equation 3: $\mathrm{Y}=\rho \mathrm{Y} 2 \mathrm{X} 1+\rho \mathrm{Y} 2 \mathrm{X} 2+\mathrm{e} 2$ 
Goenadhi, L., Mohdari., Wahyunawati, S. (2021), "In-driver online taxi and drivers behavior as a part of marketing mix program”, Management and entrepreneurship: trends of development, 3(17), pp. 68-82. Available at: https://doi.org/10.26661/2522-1566/2021-3/17-06.

\section{RESULT AND DISCUSSION}

The Effects of Product, Price, Place, and Promotion on the Consumer Satisfaction with In-Drive Taxi in Banjarmasin

\section{Analysis of Multiple Linear Regression Equation}

Multiple Linear Regression Equation

\begin{tabular}{|c|c|c|c|c|c|c|c|c|}
\hline \multicolumn{9}{|c|}{ Coefficients $^{a}$} \\
\hline \multirow{2}{*}{\multicolumn{2}{|c|}{ Model }} & \multicolumn{2}{|c|}{$\begin{array}{l}\text { Unstandardized } \\
\text { Coefficients }\end{array}$} & \multirow{2}{*}{$\begin{array}{c}\text { Standardiz } \\
\text { ed } \\
\text { Coefficien } \\
\text { ts } \\
\text { Beta }\end{array}$} & \multirow[t]{2}{*}{$\mathrm{t}$} & \multirow[t]{2}{*}{ Sig. } & \multicolumn{2}{|c|}{$\begin{array}{c}\text { Collinearity } \\
\text { Statistics }\end{array}$} \\
\hline & & B & $\begin{array}{l}\text { Std. } \\
\text { Error }\end{array}$ & & & & $\begin{array}{c}\text { Tolera } \\
\text { nce }\end{array}$ & VIF \\
\hline \multirow[t]{5}{*}{1} & (Constant) & 12.359 & 3.234 & & 4.530 & .000 & & \\
\hline & $\begin{array}{l}\text { X1 } \\
\text { (Product) }\end{array}$ & .158 & .121 & .059 & 6.584 & .001 & .969 & 1.324 \\
\hline & X2 (Price) & .167 & .276 & .437 & 8.332 & .000 & .974 & 1.332 \\
\hline & X3 (Place) & -.063 & .184 & -.124 & -2.205 & .064 & .976 & 1.217 \\
\hline & $\begin{array}{l}\text { X4 } \\
\text { (Promotion } \\
\text { ) }\end{array}$ & .071 & .135 & .236 & 4.560 & .002 & .987 & 1.301 \\
\hline
\end{tabular}

Source: Data Processing (SPSS), 2020

Based on Table 1, the linear regression equation is as follow:

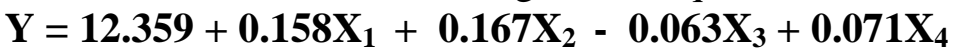

Based on the linear regression equation, the data analysis results are as follows: The value of the regression coefficient $\mathrm{X} 1$ is 0.158 . It indicated that the product had a positive and significant effect on the customer satisfaction with in-drive taxis in Banjarmasin, where the higher the quality of the existing in-drive taxi, the customer satisfaction with in-drive taxis in Banjarmasin increased as well. The value of the regression coefficient X2 is 0.167 . It showed that price positively and significantly affected the customer satisfaction with in-drive taxis in Banjarmasin, where the more affordable and competitive the taxi prices, the customer satisfaction with in-drive taxis in Banjarmasin increased as well. The value of the regression coefficient X3 is -0.063 . It meant the place negatively impacted the customer satisfaction with in-drive taxis in Banjarmasin, where the higher quality of distribution or services provided by in-drive taxis in Banjarmasin may not necessarily increase customer satisfaction. The value of the regression coefficient X4 is 0.071 . It revealed that promotion has a positive and significant impact on the customer satisfaction with indrive taxis in Banjarmasin, where the more promotions carried out to the consumers of in-drive taxis in Banjarmasin, their satisfaction increased as well. 


\section{Determination Coefficient $\left(\mathbf{R}^{2}\right)$}

\section{Results of Determination Coefficient}

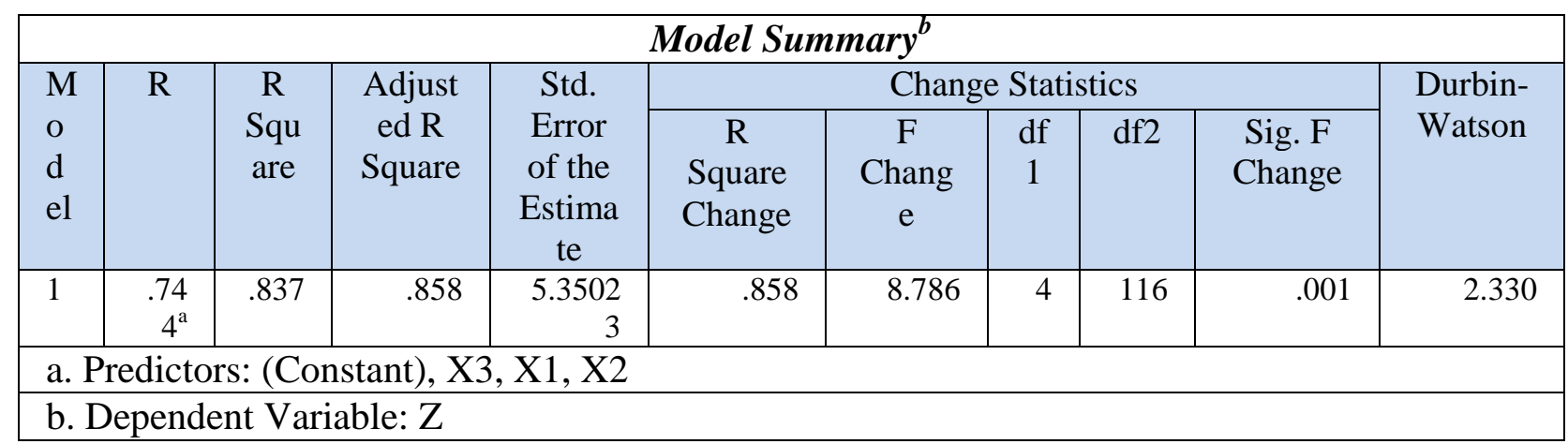

Source: Data Processing (SPSS), 2020

Based on table 2 , the adjusted $\mathrm{R}$ square value is 0.858 . In other words, $85.8 \%$ of product, price, place, and promotion had a very strong effect on consumer satisfaction with in-drive taxis in Banjarmasin, where the remaining $14.2 \%$ were caused by other variables unexplained in this study.

\section{Simultaneous Hypothesis Test}

Table 3

\section{Simultaneous Hypothesis Test}

\begin{tabular}{|c|c|c|c|c|c|c|}
\hline \multicolumn{7}{|c|}{ ANOVA $^{a}$} \\
\hline \multicolumn{2}{|c|}{ Model } & $\begin{array}{l}\text { Sum of } \\
\text { Squares }\end{array}$ & df & $\begin{array}{l}\text { Mean } \\
\text { Square }\end{array}$ & $\mathrm{F}$ & Sig. \\
\hline \multirow[t]{3}{*}{1} & Regression & 149.233 & 4 & 40.016 & 8.786 & $.001^{\mathrm{b}}$ \\
\hline & Residual & 3167.925 & 116 & 27.325 & & \\
\hline & Total & 3246.051 & 121 & & & \\
\hline
\end{tabular}

a. Dependent Variable: $\mathrm{Z}$

b. Predictors: (Constant), X3, X1, X2

Source: Data Processing (SPSS), 2020

Table 4 presents the F-count value is 8.786 higher than the F-table value of 2.45 . This explained that simultaneously, the product, price, place, and promotion had a positive and significant effect on consumer satisfaction with in-drive taxis in Banjarmasin. 
Goenadhi, L., Mohdari., Wahyunawati, S. (2021), "In-driver online taxi and drivers behavior as a part of marketing mix program”, Management and entrepreneurship: trends of development, 3(17), pp. 68-82. Available at: https://doi.org/10.26661/2522-1566/2021-3/17-06.

\section{Partial Hypothesis Test}

Partial Hypothesis Test

\begin{tabular}{|c|c|c|c|c|c|c|c|}
\hline \multicolumn{8}{|c|}{ Coefficients $^{\mathrm{a}}$} \\
\hline \multirow[b]{2}{*}{ Model } & \multicolumn{2}{|c|}{$\begin{array}{c}\text { Unstandardized } \\
\text { Coefficients }\end{array}$} & \multirow{2}{*}{$\begin{array}{c}\text { Standardized } \\
\text { Coefficients }\end{array}$} & \multirow[b]{2}{*}{$\mathrm{t}$} & \multirow[b]{2}{*}{ Sig. } & \multicolumn{2}{|c|}{$\begin{array}{c}\text { Collinearity } \\
\text { Statistics }\end{array}$} \\
\hline & B & Std. Error & & & & Tolerance & VIF \\
\hline \multirow{5}{*}{$\begin{array}{ll}1 & \text { (Constant) } \\
\text { X1 (Product) } \\
\text { X2 (Price) } \\
\text { X3 (Place) } \\
\text { X4 } \\
\text { (Promotion) }\end{array}$} & 12.359 & 3.234 & & 4.530 & .000 & & \\
\hline & .158 & .121 & .059 & 6.584 & .001 & .969 & 1.324 \\
\hline & .067 & .076 & .037 & 8.332 & .000 & .974 & 1.332 \\
\hline & -.063 & .184 & -.124 & -2.205 & .064 & .976 & 1.217 \\
\hline & .071 & .135 & .236 & 4.560 & .002 & .987 & 1.301 \\
\hline
\end{tabular}

a. Dependent Variable: Z

Source: Data Processing (SPSS), 2020

Based on Table 4, partially, only product, price, and promotion that had a positive and significant effect on consumer satisfaction with in-drive taxi in Banjarmasin. This can be proven by the $t$-count values of these three variables greater than the t-table value of 1.658.

The Effects of Product, Price, Place, and Promotion on the Drivers' Behavior of InDrive Taxi while Driving in Banjarmasin

\section{Analysis of Multiple Linear Regression Equation}

\section{Multiple Linear Regression Equation}

\begin{tabular}{|c|c|c|c|c|c|c|c|}
\hline \multicolumn{8}{|c|}{ Coefficients $^{\mathrm{a}}$} \\
\hline \multirow[b]{2}{*}{ Model } & \multicolumn{2}{|c|}{$\begin{array}{l}\text { Unstandardized } \\
\text { Coefficients }\end{array}$} & \multirow{2}{*}{$\begin{array}{c}\text { Standardized } \\
\text { Coefficients } \\
\text { Beta }\end{array}$} & \multirow[b]{2}{*}{$\mathrm{t}$} & \multirow[b]{2}{*}{ Sig. } & \multicolumn{2}{|c|}{$\begin{array}{l}\text { Collinearity } \\
\text { Statistics }\end{array}$} \\
\hline & B & Std. Error & & & & $\begin{array}{c}\text { Toleranc } \\
\mathrm{e}\end{array}$ & VIF \\
\hline 1 (Constant) & 12.347 & 3.247 & & 4.441 & .000 & & \\
\hline X1 (Product) & .166 & .126 & .064 & 6.456 & .000 & .957 & 1.315 \\
\hline X2 (Price) & .269 & .378 & .038 & 8.324 & .001 & .980 & 1.323 \\
\hline X3 (Place) & -.055 & .188 & -.128 & -1.211 & .064 & .977 & 1.218 \\
\hline $\begin{array}{l}\text { X4 } \\
\text { (Promotion) }\end{array}$ & .073 & .141 & .239 & 4.576 & .002 & .989 & 1.201 \\
\hline
\end{tabular}

a. Dependent Variable: Z

Source: Data Processing (SPSS), 2020

Based on Table 5, the linear regression equation is as follow:

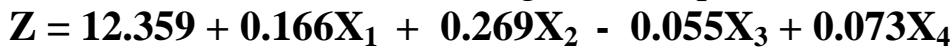


Based on the linear regression equation, the results are as follows: The value of the regression coefficient $\mathrm{X} 1$ is 0.166 . It indicated that the product had a positive and significant effect on the drivers' behavior of in-drive taxis while driving in Banjarmasin, where the higher the quality of the in-drive taxi used, the drivers' behavior while driving was better. The value of the regression coefficient $\mathrm{X} 2$ is 0.269 . It showed that price positively and significantly affected the drivers' behavior of in-drive taxis while driving in Banjarmasin, where the more affordable and competitive the in-drive taxi in Banjarmasin, the drivers' behavior while driving was better. The value of the regression coefficient value is -0.055 . It meant that place had a negative effect on the drivers' behavior of in-drive taxis while driving in Banjarmasin, where the higher quality of distribution or services provided by in-drive taxis in Banjarmasin may not necessarily improve the drivers' behavior while driving. The value of the regression coefficient $\mathrm{X} 4$ is 0.073 . It revealed that promotion positively and significantly impacted the drivers' behavior of in-drive taxis while driving in Banjarmasin, where the more promotions carried out to the consumers in Banjarmasin, the drivers' behavior while driving was better.

\section{Determination Coefficient $\left(\mathbf{R}^{2}\right)$}

Table 6

Results of Determination Coefficient

\begin{tabular}{|l|c|c|c|c|r|r|r|r|r|r|}
\hline \multicolumn{10}{|c|}{ Model Summary } \\
\hline
\end{tabular}

a. Predictors: (Constant), X3, X1, X2

b. Dependent Variable: $\mathrm{Z}$

Source: Data Processing (SPSS), 2020

The value of the regression coefficient $\mathrm{X} 1$ is 0.166 . It indicated that the product had a positive and significant effect on the drivers' behavior of in-drive taxis while driving in Banjarmasin, where the higher the quality of the in-drive taxi used, the drivers' behavior while driving was better. The value of the regression coefficient X2 is 0.269 . It showed that price positively and significantly affected the drivers' behavior of in-drive taxi drivers while driving in Banjarmasin, where the more affordable and competitive the taxi price, the drivers' behavior of indrive taxi in Banjarmasin while driving was better. The value of the regression coefficient X3 is 0.055. It meant that place had a negative effect on the drivers' behavior of in-drive taxis while driving in Banjarmasin, where the higher quality of distribution or services provided by in-drive taxis in Banjarmasin may not necessarily improve the drivers' behavior while driving. The value of the regression coefficient $\mathrm{X} 4$ is 0.073 . It revealed that promotion positively and significantly impacted the drivers' behavior of in-drive taxis while driving in Banjarmasin, where the more promotions carried out to the consumers, the drivers' behavior of in-drive taxis in Banjarmasin while driving was better. 
Goenadhi, L., Mohdari., Wahyunawati, S. (2021), "In-driver online taxi and drivers behavior as a part of marketing mix program”, Management and entrepreneurship: trends of development, 3(17), pp. 68-82. Available at: https://doi.org/10.26661/2522-1566/2021-3/17-06.

\section{Simultaneous Hypothesis Test}

Table 7

Simultaneous Hypothesis Test

\begin{tabular}{|c|c|c|c|c|c|c|}
\hline \multicolumn{7}{|c|}{ ANOVA $^{\mathbf{a}}$} \\
\hline & & $\begin{array}{l}\text { Sum of } \\
\text { Squares }\end{array}$ & df & $\begin{array}{l}\text { Mean } \\
\text { Square }\end{array}$ & $\mathrm{F}$ & Sig. \\
\hline 1 & Regression & 132.235 & 4 & 12.016 & $\overline{6.780}$ & $.001^{\mathrm{b}}$ \\
\hline & Residual & 3157.725 & 116 & 25.327 & & \\
\hline & Total & 3232.025 & 121 & & & \\
\hline
\end{tabular}

a. Dependent Variable: Z

b. Predictors: (Constant), X3, X1, X2

Source: Data Processing (SPSS), 2020

Table 7 presents the F-count value is 6.780 higher than the F-table of 2.45. This indicated that simultaneously, product, price, place, and promotion had a positive and significant effect on drivers' behavior of in-drive taxis while driving in Banjarmasin.

\section{Partial Hypothesis Test}

Table 8

\section{Partial Hypothesis Test}

\begin{tabular}{|c|c|c|c|c|c|c|c|}
\hline \multicolumn{8}{|c|}{ Coefficients $^{\mathrm{a}}$} \\
\hline \multirow[b]{2}{*}{ Model } & \multicolumn{2}{|c|}{$\begin{array}{l}\text { Unstandardized } \\
\text { Coefficients }\end{array}$} & \multirow{2}{*}{$\begin{array}{c}\begin{array}{c}\text { Standardized } \\
\text { Coefficients }\end{array} \\
\text { Beta }\end{array}$} & \multirow[b]{2}{*}{$\mathrm{t}$} & \multirow[b]{2}{*}{ Sig. } & \multicolumn{2}{|c|}{$\begin{array}{l}\text { Collinearity } \\
\text { Statistics }\end{array}$} \\
\hline & $\mathrm{B}$ & Std. Error & & & & Tolerance & VIF \\
\hline 1 (Constant) & 12.347 & 3.247 & & 4.441 & .000 & & \\
\hline X1 (Product) & .166 & .126 & .064 & 6.456 & .000 & .957 & 1.315 \\
\hline X2 (Price) & .269 & .378 & .038 & 8.324 & .001 & .980 & 1.323 \\
\hline X3 (Place) & -.055 & .188 & -.128 & -1.211 & .064 & .977 & 1.218 \\
\hline $\begin{array}{l}\text { X4 } \\
\text { (Promotion) }\end{array}$ & .073 & .141 & .239 & 4.576 & .002 & .989 & 1.201 \\
\hline
\end{tabular}

a. Dependent Variable: Z

Source: Data Processing (SPSS), 2020

Based on Table 8, partially, only product, price, and promotion had a positive and significant effect on drivers' behavior of in-drive taxis while driving in Banjarmasin. This can be proven from the t-count value for these three variables greater than the t-table value of 1.658.

The Effects of Drivers' Behavior of In-Drive Taxi while Driving on Consumer Satisfaction with In-Drive Taxi in Banjarmasin 
Simple Linear Regression Equation

\begin{tabular}{|c|c|c|c|c|c|c|c|}
\hline \multicolumn{8}{|c|}{ Coefficients $^{\mathrm{a}}$} \\
\hline \multirow[b]{2}{*}{ Model } & \multicolumn{2}{|c|}{$\begin{array}{l}\text { Unstandardized } \\
\text { Coefficients }\end{array}$} & \multirow{2}{*}{$\begin{array}{l}\text { Standardized } \\
\text { Coefficients } \\
\text { Beta }\end{array}$} & \multirow[b]{2}{*}{$\mathrm{t}$} & \multirow[b]{2}{*}{ Sig. } & \multicolumn{2}{|c|}{$\begin{array}{l}\text { Collinearity } \\
\text { Statistics }\end{array}$} \\
\hline & $\mathrm{B}$ & Std. Error & & & & Tolerance & VIF \\
\hline $1 \quad$ (Constant) & 19.876 & 2.244 & & 8.255 & .000 & & \\
\hline $\begin{array}{l}\text { Z (Drivers' } \\
\text { Behavior of } \\
\text { In-Drive } \\
\text { Taxi while } \\
\text { driving) }\end{array}$ & 2.173 & .082 & .088 & 7.740 & .001 & 1.000 & 1.000 \\
\hline
\end{tabular}

a. Dependent Variable: Y

Source: Data Processing (SPSS), 2020

Based on Table 10, the simple regression equation is as follow:

$\mathrm{Y}=\mathbf{1 9 . 8 7 6}+\mathbf{2 . 1 7 3 X _ { 1 }}$

Based on Table 9, the regression $\mathrm{Z}$ value is positive, namely 2.173. It showed that the drivers' behavior of in-drive taxis while driving in Banjarmasin positively and significantly impacted consumer satisfaction, where the better drivers' behavior of in-drive taxis while driving in Banjarmasin increased the consumer satisfaction.

Determination Coefficient $\left(\mathbf{R}^{2}\right)$

Table 10

Results of Determination Coefficient

\begin{tabular}{|c|c|c|c|c|c|c|c|c|c|c|}
\hline \multicolumn{11}{|c|}{ Model Summary $^{\text {b }}$} \\
\hline \multirow[b]{2}{*}{ Model } & \multirow[b]{2}{*}{$\mathrm{R}$} & \multirow[b]{2}{*}{$\begin{array}{c}\mathrm{R} \\
\text { Square } \\
\end{array}$} & \multirow[b]{2}{*}{$\begin{array}{l}\text { Adjusted } \\
\text { R Square }\end{array}$} & \multirow{2}{*}{$\begin{array}{c}\text { Std. Error } \\
\text { of the } \\
\text { Estimate }\end{array}$} & \multicolumn{5}{|c|}{ Change Statistics } & \multirow[b]{2}{*}{$\begin{array}{l}\text { Durbin- } \\
\text { Watson }\end{array}$} \\
\hline & & & & & $\begin{array}{c}\text { R Square } \\
\text { Change }\end{array}$ & $\begin{array}{c}\mathrm{F} \\
\text { Change }\end{array}$ & df1 & df 2 & $\begin{array}{c}\text { Sig. F } \\
\text { Change }\end{array}$ & \\
\hline 1 & $\begin{array}{r}.77 \\
5^{\mathrm{a}}\end{array}$ & .823 & .838 & 5.04231 & .823 & 6.527 & 2 & 118 & .002 & 1.662 \\
\hline
\end{tabular}

a. Predictors: (Constant), Z

b. Dependent Variable: Y

Source: Data Processing (SPSS), 2020

Table 10 presents the Adjusted R Square value is 0.838 . In other words, $83.8 \%$ of the drivers' behavior of in-drive taxis while driving in Banjarmasin strongly influenced consumer satisfaction while the remaining $16.2 \%$ were affected by other variables not described in this study.

\section{Partial Test}


Goenadhi, L., Mohdari., Wahyunawati, S. (2021), "In-driver online taxi and drivers behavior as a part of marketing mix program”, Management and entrepreneurship: trends of development, 3(17), pp. 68-82. Available at: https://doi.org/10.26661/2522-1566/2021-3/17-06.

Table 11

\section{Results of Partial Test}

\begin{tabular}{|c|c|c|c|c|c|c|c|}
\hline \multicolumn{8}{|c|}{ Coefficients $^{\mathrm{a}}$} \\
\hline \multirow[b]{2}{*}{ Model } & \multicolumn{2}{|c|}{$\begin{array}{l}\text { Unstandardized } \\
\text { Coefficients }\end{array}$} & \multirow{2}{*}{$\begin{array}{c}\begin{array}{c}\text { Standardized } \\
\text { Coefficients }\end{array} \\
\text { Beta }\end{array}$} & \multirow[b]{2}{*}{$\mathrm{T}$} & \multirow[b]{2}{*}{ Sig. } & \multicolumn{2}{|c|}{ Collinearity Statistics } \\
\hline & $\mathrm{B}$ & Std. Error & & & & Tolerance & VIF \\
\hline $1 \quad$ (Constant) & 19.876 & 2.244 & & 8.255 & .000 & & \\
\hline $\begin{array}{l}\text { Z (Perilaku } \\
\text { Driver Taksi } \\
\text { In-Drive) }\end{array}$ & 2.173 & .082 & .088 & 7.740 & .001 & 1.000 & 1.000 \\
\hline
\end{tabular}

Source: Data Processing (SPSS), 2020

Based on Table 12, the t-count value is 7.740 higher than the t-table of 1.658. It showed the drivers' behavior in-drive taxis in Banjarmasin had a positive and significant effect on consumer satisfaction.

The Effects of Product, Price, Place, and Promotion on Consumer Satisfaction with InDrive Taxi in Banjarmasin on Drivers' Behavior in Driving

The first, second, and third linear regression equation resulted in:

$\left.\mathrm{Y}=0.158 \mathrm{X}_{1}+0.167 \mathrm{X}_{2}-0,\right] .063 \mathrm{X}_{3}+0.071 \mathrm{X}_{4}$

$\mathrm{Z}=0.166 \mathrm{X}_{1}+0.269 \mathrm{X}_{2}-0.055 \mathrm{X}_{3}+0.073 \mathrm{X}_{4}$

$\mathrm{Y}=2.173 \mathrm{Z}$

Based on the regression equation, the results are as follows: The effect of product on consumer satisfaction with in-drive taxi through the drivers' behavior while driving was $=0.166 \mathrm{x}$ $0.158 \times 2.173=0.057+2.173=2.229$. Those variables positively and significantly affected each other. The effect of price on consumer satisfaction with in-drive taxi through the drivers' behavior while driving was $=0.167 \times 0.269 \times 2.173=0.098+2.173=2.271$. Those variables positively and significantly affected each other. The effect of place on consumer satisfaction with in-drive taxi through the drivers' behavior while driving was $=-0.063 \times(-0.055) \times 2.173=0.007+2.173=$ 2.180. Those variables positively and significantly affected each other. The effect of promotion on consumer satisfaction with in-drive taxi through the drivers' behavior while driving was $=0.071 \mathrm{x}$ $0.073 \times 2.173=0.011+2.173=2.184$. Those variables positively and significantly affected each other. The effect of the product on consumer satisfaction with in-drive taxis was 0.158 . Those variables positively and significantly affected each other. The effect of price on consumer satisfaction with in-drive taxis was 0.167 . Those variables positively and significantly affected each other. The effect of place on consumer satisfaction with in-drive taxis was -0.063 . Those variables negatively affected each other. The effect of promotion on consumer satisfaction with in-drive taxis was 0.071 . Those variables positively and significantly affected each other. The effect of the product on the drivers' behavior of in-drive taxis while driving was 0.166 . Those variables positively and significantly affected each other. The effect of price on the drivers' behavior of indrive taxi drivers while driving was 0.269 . Those variables positively and significantly affected each other. The effect of place on the drivers' behavior of in-drive taxi drivers while driving was 0.055. Those variables negatively affected each other. The effect of promotion on the drivers' behavior of in-drive taxi drivers while driving was 0.073 . Those variables negatively affected each other. The effect of the drivers' behavior of in-drive taxi in driving on customer satisfaction with indrive taxi was 0.166 . Those variables affected each other. 


\section{CONCLUSION}

The analysis results and discussion concluded that: The product had a positive and significant effect on consumer satisfaction with in-drive taxis in Banjarmasin. Price had a positive and significant effect on consumer satisfaction with in-drive taxis in Banjarmasin. The place had a negative effect on the consumer satisfaction with in-drive taxis in Banjarmasin. The promotion had a positive and significant effect on consumer satisfaction with in-drive taxis in Banjarmasin. The product had a positive and significant effect on the drivers' behavior of in-drive taxis while driving in Banjarmasin. Price had a positive and significant effect on the drivers' behavior of in-drive taxis while driving in Banjarmasin. The place had a negative effect on the drivers' behavior of in-drive taxis while driving in Banjarmasin. The promotion had a positive and significant effect on the drivers' behavior of in-drive taxis while driving in Banjarmasin. The drivers' behavior of in-drive taxis while driving has a positive and significant effect on consumer satisfaction with in-drive taxis in Banjarmasin. Product, price, place, and promotion affected the consumer satisfaction with indrive taxis in Banjarmasin through the drivers' behavior while driving.

\section{REFERENCES}

Nurul, A., (2013), “Analisis Penentuan Harga Jual Perkemansn Produk Terhadap Laba Yang Dihasilkan PT INDOFOOD”. CBP Sukses Makmur Tbk Palembang, Scientific Journal. Available at: https://www.academia.edu/19776377/ (Accessed 20 May 2021), (in Indonesian).

Assauri, S. (2008). Production and Operations Management. Jakarta : Publishing Institute, Faculty of Economics, University of Indonesia. 85-90.

Wawan, A., \& Dewi, M. (2014). Teori \& Pengukuran Pengetahuan, Sikap, dan Perilaku Manusia. Available at: https://kink.onesearch.id/Record/IOS3254.slims-2329/Details (Accessed 20 May 2021), (in Indonesian).

Bilson, S., (2002), Panduan Riset Perilaku Konsumen, Jakarta: Gramedia Pustaka Utama. Available at: https://books.google.co.id/books (Accessed 28 May 2021), (in Indonesian).

Fandy, Tjiptono. (2011), Service Management Realizing Excellent Service. Edition 2. Yogyakarta : Andi. (in Indonesian).

Jakaria, D., and Esti, S., (2012), Pengaruh Kualitas Produk dan Promosi Penjualan terhadap Keputusan Pembelian pada Distro Screamous. Prosiding Manajemen, p. 1246-1254. Available at: http://103.78.195.33/handle/123456789/25534?show=full (Accessed 20 May 2021), (in Indonesian).

Kotler, Ph. and Keller, K. (2009). Marketing Management. Volume I. 13th Edition. Jakarta: Erlangga Available

at: https://www.researchgate.net/publication/225084026_Marketing_Management (Accessed 20 May 2021), (in English).

Kotler, F., Kartajaya, H. and Setiawan, I. (2010), Marketing 3.0. Simon \& Schuster, England. Available at: https://doi.org/10.1002/9781118257883.

Lupiyoadi, R. and Hamdani, A. (2014), Manajemen pemasaran jasa, Jakarta : Salemba Empat. (in Indonesian).

Nazir, Moh., (1988), Metode penelitian, Jakarta : Ghalia Indonesia, 544 p. (in Indonesian).

Notoatmodjo, S., (2010), Ilmu Kesehatan Perilaku, Jakarta : PT Rineka Cipta. Available at: http://repository.ui.ac.id/dokumen/lihat/5848.pdf (Accessed 20 May 2021), (in Indonesian).

Oentoro, D., (2010), Manajemen Pemasaran Modern, Yogyakarta : Laksbang Pressindo, (in Indonesian).

Saladin, Dj., (2002), Marketing Management, First Edition, Bandung : Linda Karya, (in Indonesian). 
Goenadhi, L., Mohdari., Wahyunawati, S. (2021), "In-driver online taxi and drivers behavior as a part of marketing mix program”, Management and entrepreneurship: trends of development, 3(17), pp. 68-82. Available at: https://doi.org/10.26661/2522-1566/2021-3/17-06.

Sugiyono, (2017), Metode Penelitian Kuantitatif, Kualitatif, dan Litbang, Bandung : Alfabeta, (in Indonesian).

Zeithaml, VA. and Bitner, MJ., (1996), Menyampaikan dan Melakukan Layanan, Bagian Lima, Pemasaran Layanan Internasional Ed, The McGraw-Hill Inc, (in Indonesian).

\section{ОН-ЛАЙН ТАКСІ ТА ПОВЕДІНКА ВОДІЇВ ЯК СКЛАДОВА МАРКЕТИНГОВОЇ МІХ ПРОГРАМИ}

\author{
Lydia Goenadhi \\ Sekolah Tinggi Ilmu Ekonomi Indonesia \\ Banjarmasin, Indonesia
}

\author{
Mohdari \\ STIE Nasional Banjarmasin \\ Banjarmasin, Indonesia
}

\author{
Sri Wahyunawati \\ STIE Dahani Dahanai Buntok \\ Indonesia
}

В даний час в Індонезії функціонують як громадський транспорт, що перевозить людей та вантажі, так і приватні транспортні засоби (автомобілі), в тому числі онлайн -таксі. Поряд 3 прогресом технологій, нинішні програми вводять послуги замовлення онлайн -таксі 3 використанням технологій і стандартів обслуговування. Виходячи з цього, в Банджармасин існують постачальники послуг онлайн-таксі, такі як Grab-Car, Go-Car, Maxim i In-Driver. Bci послуги, що надаються ними, майже однакові - при сістемами бронювання використовується додаток, встановлений на мобільному телефоні. Але постачальники мають різні ціни. Постійно з'являються нові онлайн -таксі, що викликає ще більшу конкуренцію. Ця конкуренція виникає тому, що ціна і послуга є факторами, що визначають задоволеність $\mathrm{i}$ переваги споживачів. Онлайн-компанії таксі намагаються створити якісні послуги i відповідні ціни, щоб задовольнити споживачів. Це дослідження мало на меті визначити роль програми mix маркетингу і досліджувати рівень задоволеності замовника онлайн-таксі в Банджармасин. Об'єктом даного дослідження є 121 споживач онлайн-таксі в Банджармасин. Результати цього дослідження показали, що продукт, ціна і просування позитивно і суттєво вплинули на рівень задоволеності замовника від використання онлайн-таксі в Банджармасин. Зазначені три змінні також позитивно і суттєво вплинули на поведінку водіїв під час руху в Банджармасин. Одночасно продукт, ціна, місце і просування мали позитивний і значний вплив на рівень задоволеності замовника таксі в Банджармасин.

Ключові слова: товар, ціна, акція, місце, поведінка водія, задоволеність споживачів, онлайн -таксі.

\section{ОН-ЛАЙН ТАКСИ И ПОВЕДЕНИЕ ВОДИТЕЛЕЙ КАК СОСТАВЛЯЮЩАЯ МАРКЕТИНГОВОЙ МІХ ПРОГРАММЫ}

\author{
Lydia Goenadhi \\ Sekolah Tinggi Ilmu Ekonomi Indonesia \\ Banjarmasin, Indonesia
}

\author{
Mohdari \\ STIE Nasional Banjarmasin \\ Banjarmasin, Indonesia
}

Sri Wahyunawati

STIE Dahani Dahanai Buntok

Indonesia

В настоящее время в Индонезии функционируют как общественный транспорт, перевозящий людей и грузы, так и частные транспортные средства (автомобили), в том числе 
такой вид транспорта как онлайн -такси. Современные программы вводят услуги заказа онлайн -такси с использованием технологий и стандартов обслуживания. Исходя из этого, в Банджармасин существуют поставщики услуг онлайн-такси, такие как Grab-Car, Go-Car, Maxim и In-Driver. Все услуги, предоставляемые ими, почти одинаковы - при системе бронирования используется приложение, установленное на мобильном телефоне, но поставщики имеют разные цены. Постоянно появляются новые онлайн -такси, что вызывает еще большую конкуренцию. Эта конкуренция возникает потому, что цена и услуга являются факторами, определяющими удовлетворенность и предпочтения потребителей. Онлайнкомпании такси пытаются создать качественные услуги и соответствующие цены, чтобы удовлетворить потребителей. Целью исследования является определение роли программы mix маркетинга и исследование удовлетворенности потребителей онлайн-такси в Банджармасин. Объектом данного исследования является 121 потребитель онлайн-такси в Банджармасин. Результаты этого исследования показали, что продукт, цена и продвижение положительно и существенно повлияли на удовлетворенность потребителей от использования онлайн-такси в Банджармасин. Эти три переменные также положительно и существенно повлияли на поведение водителей во время движения в Банджармасин. Одновременно продукт, цена, место и продвижение имели положительный и значительное влияние на удовлетворенность потребителей такси в Банджармасин.

Ключевые слова: товар, цена, акция, место, поведение водителя, удовлетворенность потребителей, онлайн -такси. 